\title{
Postpartum Haemorrhage Occurrence Seen from Influencing Factors
}

\author{
Titin Susiyanti, Byba Melda \\ Suhita, Nurdina \\ Prof. dr. Soekandar Hospital, \\ Mojokerto, Indonesia \\ Email: \\ gindasusiyanti@gmail.com
}

Received: March 12, 2019

Accepted : October 13, 2019

Published : November 26, 2019

\begin{abstract}
The biggest cause of maternal mortality rates in developing countries, one of which is bleeding after childbirth or commonly called postpartum hemorrhage (PPP). This study was conducted to determine factors that influence the incidence of postpartum hemorrhage. Observational research design with a case control approach. held on 1 - 31 August 2018 with a population of 109 people and a sample of 90 mothers giving birth, sample random sampling technique. Data collection is independent and dependent variable by observation and questionnaire. Data analysis uses logistic regression test. Based on the results of logistic regression test obtained variable bleeding history postpartum $p$ value value of 0.019 , preeclampsia $p$ value of 0.012 , anemia $p$ value of 0.009 at $\alpha=0.05$, the effect of the incidence of postpartum hemorrhage was influenced by a history of postpartum hemorrhage, preeclampsia and anemia significantly. Anemia is a dominant risk factor contributing to the incidence of postpartum hemorrhage. It is recommended that pregnant women take precautions as early as possible with regular pregnancy checks, knowing the factors preventing the occurrence of postpartum hemorrhage, be more careful to prevent complications at the time of delivery.
\end{abstract}

Keywords : Postpartum Bleeding, Parity, Preeclampsia, Oxytocin Drip, Anemia, HPP History 


\section{INTRODUCTION}

The biggest cause of maternal mortality rates in developing countries, one of which is bleeding after childbirth or commonly called post partum hemorrhage (PPH). Post partum hemorrhage cannot be predicted beforehand. The incidence of postpartum hemorrhage is mostly due to uterine atony (Maternal Child and Health Integrated Program, 2011).

Maternal Mortality Rate (MMR) in Indonesia is still high when compared to countries in Southeast Asia, where in 2007 MMR in Indonesia increased from 228 per 100,000 KH to 359 per $100,000 \mathrm{KH}$ in 2012 (IDHS, 2012). The cause of high maternal mortality rates in Indonesia is very complex, namely bleeding, preeclampsia, infection, postpartum. Mortality Report (IFI), the target for MMR is 305 per 100,000 live births. In 2016, the MMR of East Java Province reached 91.00 per 100,000 live births. This figure has increased compared to 2015 which reached 89.6 per 100,000 live births. The highest cause of maternal death in 2016 was Preeclampsia / Eclampsia, namely amounting to $30.90 \%$ or as many as 165 people, bleeding is $28.65 \%$,

Another cause is $24.72 \%$, the heart is $10.86 \%$, while the smallest cause is infection at $4.87 \%$ or as many as 26 people. The number of maternal deaths in Mojokerto Regency was 22 cases, the highest cause was Preeclampsia / Eclampsia which was 5 people, bleeding was 3 people, infection was 1 person, amniotic embolism was 2 people, Ruptura Uterus Interna (RUI) was 2 people, another cause was 6 people, the heart is 3 people Data at Prof. dr. Soekandar, Mojokerto Regency, the maternal mortality rate in 2016 was 5 cases, the causes of which were 2 Preeclampsia 2 people with complications of pulmonary edema and cardiomegaly, 1 hemorrhage (uterine atony) 1 person, amniotic embolism 1 person, Heart and 1 pneumonia Prof.dr. Soekandar, 2016).

All women who are 20 weeks pregnant have a risk of post partum hemorrhage. Post partum hemorrhage is the most common cause of maternal death. Although maternal mortality rates have dropped dramatically in developing countries, post partum hemorrhage is the most common cause of maternal death. (Marmi, 2012).

The Standard of Government Efforts to accelerate the reduction of MMR can be done by ensuring that every mother is able to access quality maternal health services, such as maternal health services, delivery assistance by trained health workers in health care facilities, postpartum care for mothers and babies, special care and referral if complications occur, ease of obtaining maternity and maternity leave and family planning services (Indonesian Health Profile Ministry of Health RI, 2017)

Based on the above background, the researchers are interested in taking research on "Post Partum Bleeding Events in terms of the factors that influence the hospital Prof. dr. Soekandar, Mojokerto Regency.

\section{MATERIALS AND METHODS}

This research is an observational research design with a case control approach is an observational analytic epidemiological study that examines the relationship between effects (diseases or health conditions) with certain risk factors (Sudigdo, 2014). The sampling technique of this study uses simple random sampling. The instrument used in this study is to measure blood pressure and laboratory results, using original documents or investigations, and observations. The population in this study were all maternity mothers who gave birth in the maternity hospital Prof. dr. Soekandar, Mojokerto Regency on August 1-31 2018, as many as 109 mothers gave birth, a large sample of 90 mothers gave birth.

The independent variables in this study were parity, preeclampsia, oxytocin drip, anemia of pregnancy, past bleeding history. The dependent variable is the incidence of postpartum hemorrhage. Data analysis techniques were carried out using the Logistic Regression analysis test.

\section{RESULT \\ Description of parity, preeclampsia, oxytocin drip, anemia, and history of past labor bleeding at maternity labor at Prof.dr Soekandar Hospital .}

Table 1 shows mothers giving birth at Prof. dr. Soekandar the majority of respondents were multiparous parity of $64.4 \%$ and the grandemultipara was only $6.7 \%$. Preeclampsia status of respondents divided into two, first preeclampsia if the results of blood pressure examination>130/90 $\mathrm{mmHg}$, urine protein laboratory results $>+1$, ema feet and second not preeclampsia if blood pressure testing results, normal urine protein and not odema. Nearly half of the respondents experienced 
preeclampsia by $43.3 \%$. Most of the respondents did not get Oxytocin drip therapy for $85.6 \%$ and only a small proportion of those who received oxytocin therapy. The anemia status of the respondents was divided into two, the first was anemia if the results of $\mathrm{Hb}$ levels were $<10 \mathrm{gr} \%$ and the second was not anemia if the $\mathrm{Hb}$ level was $\geq 10 \mathrm{gr} \%$. A small percentage of respondents experienced anemia, namely $31.1 \%$. Nearly a small percentage of respondents who experienced a history of past labor hemorrhage of $5.6 \%$ even then occurred in multiparous.

Table 1 Distribution of Parity, Preeclampsia, Oxytocin drip, Anemia and History of past labor bleeding at Prof. dr. Soekandar, Mojokerto Regency

\begin{tabular}{lcc}
\hline \multicolumn{1}{c}{ Variable } & Frekunsi & $(\%)$ \\
\hline Parity & 26 & 28,9 \\
Primipara & 58 & 64,4 \\
Multipara & 6 & 6,7 \\
Grandemultipara & & \\
Preeklampsia & 38 & 43,3 \\
Yes & 51 & 56,7 \\
No & & \\
Oxytocin drip & 13 & 14,4 \\
Yes & 77 & 85,6 \\
No & & 31,1 \\
Anemia & 28 & 68,9 \\
Yes & 62 & 5,6 \\
No & & 94,4 \\
Bleeding history & 5 & \\
Yes & 85 & \\
No & & \\
\hline
\end{tabular}

\section{Cross Tabulation of Occurrence of Postpartum Bleeding with Factors Affecting Childbirth}

Respondents who had multiparous parity in a small proportion experienced postpartum hemorrhage with a percentage of $10.0 \%$. Respondents who experienced a small portion of preeclampsia experienced postpartum hemorrhage with a percentage of 13.35. Respondents who did not receive oxytocin drip therapy were a small percentage who experienced postpartum hemorrhage with a percentage of $15.6 \%$. Respondents who experienced anemia were a small proportion who experienced postpartum bleeding with a percentage of $12.2 \%$. Respondents who had a history of past labor bleeding recurred again postpartum with a percentage of $3.3 \%$. Significant $=0.05$. Variable preeclampsia, anemia and past labor bleeding history. 
Table 2 Postpartum haemorrhage events in terms of influencing factors

\begin{tabular}{|c|c|c|c|c|}
\hline \multirow{3}{*}{ Variable } & \multicolumn{4}{|c|}{ Variable Postpartum Hemorrhage } \\
\hline & \multicolumn{2}{|c|}{ Bleeding Events } & \multicolumn{2}{|c|}{ No Bleeding } \\
\hline & $\mathrm{F}$ & $\%$ & $\mathrm{~F}$ & $\%$ \\
\hline \multicolumn{5}{|l|}{ Parity } \\
\hline Primipara & 6 & 6,7 & 20 & 22,2 \\
\hline Multipara & 9 & 10,0 & 49 & 54,4 \\
\hline Grandemultipara & 1 & 1,1 & 5 & 5,6 \\
\hline \multicolumn{5}{|l|}{ Preeclampsia } \\
\hline Yes & 12 & 13,3 & 27 & 30,0 \\
\hline No & 4 & 4,4 & 47 & 52,2 \\
\hline \multicolumn{5}{|l|}{ Oxytocin drip } \\
\hline Yes & 2 & 2,2 & 11 & 12,2 \\
\hline No & 14 & 15,6 & 63 & 70,0 \\
\hline \multicolumn{5}{|l|}{ Anemia } \\
\hline Yes & 11 & 12,2 & 17 & 18,9 \\
\hline No & 5 & 5,6 & 57 & 63,3 \\
\hline \multicolumn{5}{|l|}{ Bleeding History } \\
\hline Yes & 3 & 3,3 & 2 & 2,2 \\
\hline No & 13 & 14,4 & 72 & 80,0 \\
\hline
\end{tabular}

Effect of parity, preeclampsia, oxytocin drip, anemia, and past history of labor bleeding on the incidence of postpartum hemorrhage

The results of the multivariate logistic regression test obtained three significant variables namely preeclampsia, anemia and past labor bleeding history. These three variables have a value of $\rho$ which is smaller than the significant value $=0.05$. Variable preeclampsia has a value of $\rho=0.10$. The results showed that mothers who had preeclampsia were at risk of having 8,776 times the risk of having postpartum hemorrhage compared with those who did not experience preeclampsia. Variable anemia has a value of $\rho=0.017$ and maternity mothers who give birth with anemia have a risk of 4.952 having postpartum hemorrhage during labor compared with mothers who do not have anemia. Past variables of labor bleeding have a value of $\rho=0.014$ and maternity mothers with a past history of labor bleeding have a risk of 24,534 having postpartum hemorrhage during labor compared with mothers who did not have a past history of labor bleeding.

Table 3 Multivariate analysis with logistic regression partially phase I

\begin{tabular}{|c|c|c|}
\hline Variable & $\operatorname{Sig}(\rho)$ & $\operatorname{Exp}(B)$ \\
\hline Parity & 0,426 & 1,618 \\
\hline Preeclampsia & 0,010 & 8,776 \\
\hline Oxytocin drip & 0,916 & 1,113 \\
\hline Anemia & 0,017 & 4,925 \\
\hline Bleeding History & 0,014 & 24,534 \\
\hline
\end{tabular}

The results of the Phase II multivariate logistic regression test obtained three significant variables namely preeclampsia, anemia and past labor bleeding history. These three variables have a value of $\rho$ which is smaller than the significant value $=0.05$. Variable preeclampsia has a value of $\rho=$ 0.12 the results of the study show that mothers who have preeclampsia are at risk of having a risk, 931 times having postpartum hemorrhage compared with women who did not experience preeclampsia. Variable anemia has a value of $\rho=0.009$ and maternity mothers who deliver with anemia have a risk of 5.490 experiencing postpartum hemorrhage during labor compared with mothers who did not experience anemia. Past variance in labor hemorrhage history has a value of $\rho=0.019$ and maternity mothers with a past history of labor bleeding have a risk of 19,672 having postpartum hemorrhage during labor compared with mothers who did not have a past history of labor bleeding. The more dominant variable is anemia 
Table 4 Multivariate analysis with partial logistic regression stage II

\begin{tabular}{lcc}
\hline Variable & Sig $(\rho)$ & Exp $(\mathrm{B})$ \\
\hline Preeclampsia & 0,012 & 7,931 \\
Anemia & 0,009 & 5,490 \\
Bleeding History & 0,019 & 19,672 \\
\hline
\end{tabular}

\section{DISCUSSION \\ Parity Effect on Postpartum Bleeding Events}

The results showed that out of 90 respondents there were 58 respondents $(64.4 \%)$ who were multipara could experience postpartum haemorrhage and logistic regression test results obtained $\mathrm{P}$ value 0.426 greater than the value of $\alpha=(0.05)$, so that there was no effect of multiparous parity has an opportunity of 1,618 times to experience postpartum hemorrhage compared to primipara and grandemultipara parity.

Shows that parity is not a factor causing postpartum hemorrhage, this can be influenced by several factors including parity is not a direct factor that causes postpartum hemorrhage, other than that most of the respondents in this study are not at risk (2-3).

This study is in accordance with the theory of Manuaba (2009) which states that parity 2-3 is the safest parity in terms of postpartum hemorrhage angle. Parity 1 and high parity (more than 3 ) have the incidence of postpartum hemorrhage is higher. In low parity (one parity), maternal unpreparedness in the face of the first delivery is a factor causing the inability of pregnant women to deal with complications that occur during pregnancy, childbirth and childbirth. While in high parity (more than three), reproductive function has decreased so that the possibility of postpartum hemorrhage is greater. According to Bobak (2004), for women with a history of parity 1 time they read a lot of books, seek information through developing electronic media, attend classes for pregnant women and communicate with other women (mothers, sisters and friends).

In women with a history of parity 2-3 times they already have experience of pregnancy and maternity before, thus influencing themselves in preparing for childbirth so that labor is normal. In women with a history of parity more than equal to 4 times, it is likely that some of their body condition and function are still good yet to show symptoms and signs of complication in pregnancy and childbirth. In addition, the experience at the time of delivery made him more cautious and alert in acting. These results may influence the statistical test of the effect of parity on the incidence of postpartum hemorrhage, so the results of statistical tests showed no effect of parity variables on the incidence of postpartum hemorrhage.

\section{Effect of Preeclampsia on Postpartum Bleeding}

The results showed that out of 90 respondents there were 53 respondents $(56.7 \%)$ who were not preeclampsia could experience postpartum haemorrhage and logistic regression test results with $p$ value of 0.010 smaller than the value of $\alpha=(0.05)$ so that there is an effect of preeclampsia with the incidence of postpartum hemorrhage. Preeclampsia has an opportunity to experience postpartum hemorrhage 8,776 times compared with those without preeclampsia.

Preeclampsia often occurs in the first pregnancy, this condition is caused immunologically that in the first pregnancy the formation of blocking antibodies to the placental antigen is imperfect, resulting in an unfavorable immune response to placental histo-compatibility (Manuaba, 2010). Preeclampsia is the onset of hypertension with proteinuria and edema due to pregnancy after 20 weeks of gestation or immediately after delivery (Maryunani, 2009) According to the 2014 Indonesian Health Profile, the four biggest causes of maternal death are 30.3\% bleeding, pregnancy hypertension (HDK) 27, 1\%, infection $7.3 \%$, etc. that is the cause of indirect maternal death such as the condition of cancer, kidney, heart or other diseases suffered by the mother by 35.3\% (Ministry of Health RI, 2014).

The condition of preeclampsia or the condition of eclampsia in pregnant women is often a separate case that can contribute to morbidity and mortality in the condition of pregnant women. This situation occurs because of the factors that many pregnant women know about, namely neglect of food that triggers blood pressure, age when pregnant is not noticed and aspects of readiness during pregnancy that can affect the level of body immunity in pregnant women. If a health worker / midwife meets a pregnant patient with preeclampsia in a state of childbirth, the midwife conducts counseling to the 
patient and family about the condition of the patient and must immediately refer to the hospital that needs further treatment and to prevent complications at birth and postpartum period.

\section{Effect of oxytocin drip on postpartum haemorrhage}

The results showed that out of 90 respondents there were 77 respondents $(85.6 \%)$ who did not have oxytocin drip could experience postpartum haemorrhage logistic regression test with a $\mathrm{P}$ value of 0.916 so that there was no the association of oxytocin drip with the incidence of postpartum haemorrhage and those not on oxytocin drip had a 1.113 chance to experience postpartum hemorrhage compared with those given oxytocin drip.

Oxytocin drip stimulation with the aim of acceleration at low doses can increase the strength and frequency of contractions, but in high doses can cause uterine tetania to develop extensive maternal birth trauma and cause bleeding and inversion of the uterus. While oxytocin drip stimulation with the aim of induction causes excessive stimulation of the uterus so that it experiences overdistention (excessive stretching of the uterus) and causes hypotonia after childbirth (Varney, 2011).

From the above conditions researchers can assume that drip oxytocin can stimulate uterine contractions that have not contracted and increase the strength and frequency of contractions in the contracting uterus. Oxytocin drip stimulation with the aim of acceleration at low doses can increase the strength and frequency of contractions, but in high doses can cause uterine tetania to occur extensive maternal birth trauma and cause bleeding and inversion of the uterus. While oxytocin drip stimulation with the aim of induction causes excessive stimulation of the uterus so that it overdistates (excessive stretching of the uterus) and causes hypotypototonia after childbirth

\section{Effect of anemia on the incidence of postpartum hemorrhage}

The results showed that out of 90 respondents there were 62 respondents $(68.9 \%)$ who were not anemic who could experience postpartum haemorrhage and logistic regression test results with a $p$ valuen of 0.017 so that there was a relationship of anemia with the incidence of postpartum hemorrhage and pregnant women who did not have anemia. 4.952 times the chance of not having postpartum hemorrhage compared with those with anemia.

According to Manuaba (2008), pregnant anemia is called "potential danger to mother and child" anemia (potential harm to mother and child). Therefore anemia requires serious attention and all parties involved in health services in the future. Anemia in pregnant women is a condition in which red blood cells decrease or decrease in hemoglobin, so that the capacity of oxygen carrying capacity for the needs of vital organs in the mother and fetus is reduced. During pregnancy, an indication of anemia is if the hemoglobin concentration is less than 10.5 to $11.0 \mathrm{~g} / \mathrm{dl}$.

Fundamental Causes; Nutritional anemia is more common in the population group as follows: Low education; because in general: (lack of understanding of the link between anemia and other factors, lack of access to anemia information and overcoming it, less able to choose nutritious foods, especially those containing iron is relatively high, less able to use available health services. Low economy because, because they are less able to buy food as a source of iron because the price is relatively expensive, lack of access to available health services, the social status of women who are still low in the community has several consequences that facilitate the onset of nutritional anemia.

women's education is lower than men.

According to Arisman (2008) that nutrition in pregnant women greatly determines the health status of the mother and fetus. Factors that can affect the nutritional status of pregnant women are: family socioeconomic condition of pregnant women; to fulfill nutrition, it requires adequate financial resources, maternal health and nutrition; the ability to consume nutrients is reduced by the mother in a state of pain so that an increase in body metabolism occurs. For that, more intake is needed, birth distance; if the conceived is not the first child, short birth spacing causes the reproductive function function is still not optimal, Age the first pregnancy, age above 35 years is the risk of complicating labor and the decline in the functions of the reproductive organs, the habit of pregnant women consume drugs, alcohol, smokers and coffee users.

Anemia Management Efforts Efforts to overcome nutritional anemia, especially in pregnant women, have been implemented by the government. One way is through iron tablet supplementation. Iron tablet supplementation is considered an effective way because the iron content is solid and is supplemented with folic acid which can simultaneously prevent and overcome anemia due to folic acid 
deficiency. This method is also efficient because iron tablets are relatively cheap and can be reached by the lower class and easily available (MOH: 20008).

\section{Effect of past labor bleeding on postpartum bleeding}

The results showed that out of 90 respondents there were 85 respondents $(94.4 \%)$ who did not have a past history of labor bleeding, could experience postpartum haemorrhage and logistic regression test results with $\mathrm{p}$ value of 0.014 so that there was a relationship of past labor bleeding history with incidence Postpartum hemorrhage and a past history of labor bleeding have a 24,534 times chance of experiencing postpartum hemorrhage compared with those who did not have a past history of labor bleeding.

Past labor with action is one of the factors causing postpartum hemorrhage. Past deliveries with actions include delivery of vaginal action is by vacuum and forceps, while the action of abdominal delivery is Sectio Caesaria. Actions in both vaginal and abdominal labor can cause trauma both to the mother and to the baby (Manuaba, 2009).

This must indeed be considered by every pregnant woman and officers, especially midwives, because a history of bleeding in past labor also has a risk of bleeding in the process of labor / subsequent pregnancy. This condition occurs also affects the condition of physical conditions in pregnant women such as past labor history with vacuum or surgery, previous contraception, and inadequate pregnancy activity.

\section{Dominant Factors that Affect the Occurrence of Postpartum Bleeding}

The results were obtained from the logistic regression test with a P value of: 0.009 with $\leq \alpha$ (0.05), the incidence of postpartum hemorrhage was most influenced by the condition of anemia when pregnant women. Most pregnant women experience anemia that is not harmful. However, anemia due to congenital abnormalities in hemoglobin can complicate pregnancy

These disorders increase the risk of illness and death in newborns and increase disease in the mother (Maulana, 2012). The most common anemia experienced by mothers is iron deficiency anemia. This is not surprising because lack of protein causes reduced hemoglobin formation and red blood cell formation. While reduced hemoglobin in the blood causes it to disappear or reduced iron in the blood (Lamadhah, 2008).

Increased professionalism in the ability of midwives (BPM) health workers in active management of the third stage of labor, increased understanding of high risk pregnancies and midwife compliance in referral of high-risk pregnant women to referral health care facilities. There needs to be a recording \& reporting system that ensures data availability for various pregnancy, childbirth and risk factors as evidence that is useful for planning, mapping and evaluating program activities.

\section{CONCLUSION}

Based on the five variables, namely parity, preeclampsia, oxytocin drip, anemia and past labor bleeding history, there were three significant variables, namely preeclampsia, anemia and past labor bleeding history against the incidence of postpartum hemorrhage. Variable preeclampsia in women who are not preeclampsia has a lower risk of postpartum hemorrhage compared to mothers who have preeclampsia. Maternity mothers who are not anemic have a lower risk of having labor with postpartum hemorrhage compared with mothers who experience anemia during childbirth. Pregnant women who do not have a past history of labor bleeding have a lower risk of having labor with postpartum hemorrhage compared with mothers who have a history of past labor bleeding.

\section{REFERENCES}

Arikunto. (2010). Research procedure: a practical approach, Jakarta: Rineka Cipta.

Arisman. (2008). Nutrition in the Life Cycle. Buku Kedokteran, Jakarta.

Cunningham, F., G., et al. (2013). William obstetrics 20th edition. Prentice-Hall International, Inc. 2008: Diagnosis of After Disease After Childbirth. Jakarta: EGC.

Desi, \& Dwi. (2009). Nutrition in Reproductive Health. Nuha Medika.Yogyakarta. 
RI Ministry of Health. (2012). Indonesian Health Demographic Survey. MOH, Jakarta.

RI Ministry of Health. (2004). Director General of Public Health Development, Operational Guidelines Tackling Nutrition Anemia in Indonesia. Jakarta.

RI Ministry of Health, \& Towards Healthy. (2020). Jakarta.

Diana. (2008). Anemia in Pregnant Women. EGC. Jakarta.

District Health Office Mojokerto. (2016). Profile of the Mojokerto District Health Office.

Jawa Timur Health Office. (2016). East Java Health Office Profile.

Gibson. (2008). Human Resource Management, fourth edition, Erlangga. Jakarta.

Hidayat, A., A. (2010). Nursing Research and Scientific Writing Techniques. Jakarta: Salemba Medika.

RI Ministry of Health. (2013). Pocket book for Maternal Health Services in Basic Health Facilities and Referrals. Jakarta.

RI Ministry of Health. (2016). Indonesian Health Profile. Jakarta: Ministry of Health RI.

RI Ministry of Health. (2016). Ministry of Health's Data and Information Center. Jakarta.

Manuaba, \& Ayu, I. (2008). Emergency Obstetric Gynecology and Social Obstetrics for Midwives. Jakarta: ECG.

Manuaba, \& Ayu, I. (2010). Obstetrics, Gynecology and Family Planning for Midwife Education. Jakarta: ECG.

Marmi. (2012). Intranatal Care. Yogyakarta: Student Library.

Martono, \& Nanang. (2012). Quantitative Research Methods: Analysis Secondary Data Fill and Analysis, Ed. Revision. Jakarta: Rajawali Press.

Murti, B. (2010). Design and Sample Size for Qualitative and Quantitative Research in the field of health. Yogyakarta: Gadjah Mada University Press.

Notoatmodjo, \& Soekidjo. (2010). Health Research Methodology. Jakarta: Rineka Cipta.

Notoadmojo, \& Soekidjo. (2012). health and health behavior. Jakarta Creative makeup.

Nugroho, \& Taufan. (2012). Midwifery Pathology, Nuha Medika, Yogyakarta.

Nursalam. (2008). Concept and Application of Research Methodology for Nursing Sciences. Surabaya: Salemba Medika.

Nursalam. (2016). Concept and Application of Nursing Research Methodology. Jakarta: Salemba Medika.

Prawirohardjo, S. (2011). Midwifery. Jakarta: Bina Pustaka Foundation Sarwono Prawirohardjo. 2010. Midwifery. Jakarta: Bina Pustaka Foundation Sarwono Prawirohardjo. 
Rachmawati, EN. (2011). Practical Midwifery Science. Victoria Inti Cipta.

Rochjati, P., (2011). Antenatal Screening for Pregnant Women. Surabaya: FK UNAIR.

Rustam. (2010). Multipara and Grandemultipara. Yogyakarta: Nuha Medika.

Ruswana. (2009). Health for Pregnancy High Risk. Jakarta: Salemba Medika.

Lumbanraja, S., N. (2017). Obstetric Emergency. Medan: USU PRESS.

Saifuddin, A., B., Adruaansz, G., Wiknjosastro, G., H., \& Waspodo, D. (2008). National Reference Book for Maternal and Neonatal Health Services. Issue 1. 5th print. Jakarta: Bina Pustaka Foundation Sarwono Prawiryoharjo.

Sarwono. (2008). Midwifery. 4th Edition, Mold I. Jakarta: Bina Pustaka Foundation Sarwono Prawirohardjo.

IDHS. (2012). Indonesian Demographic and Health Survey. Jakarta: Central Statistics Agency.

Varney. (2011). Gynecological Obstetrics Theory. Jakarta: EGC zi-dengan-lila.html?m=1 